\title{
Australian Responses to the ARMENian GENOCIDE, 1915-1930
}

\section{VICKEN BABKENIAN}

In December 1915, Charles E W Bean, the Australian war correspondent in Gallipoli, reported that the Turks as the world knows' are endeavouring 'to wipe out the Armenian nation'. ${ }^{1}$ Bean had observed an event which would later be widely recognised as the first major genocide of the twentieth century. ${ }^{2}$ At the time, every major newspaper in Australia regularly covered the genocide - the Sydney Morning Herald alone published more than 50 articles on the event in 1915. Headings like 'Armenians Butchered', 'Million Armenians Massacred' and 'More Armenians Massacred-girls sold in open market' were common and indicated the tone of the articles at that time. ${ }^{3}$ Emerging from a world-wide movement to save the survivors of the Turkish onslaught, a relief fund was established in Australia in late 1915 and it continued for more than a decade.

While the Australian citizenry was learning about the fate of the Armenians through the media, Australian and New Zealand (ANZAC) prisoners of war captured by the Ottoman Turks were witnessing first hand the unfolding of the murderous events. Yet, despite the strong connection between

${ }^{1}$ Bean, Charles E W (1915), 'Germany's Al - the Turkish method', Mercury, 21 December, 6.

2 See international affirmation of the Armenian genocide, http://www.armenian-genocide.org/affirmation.html accessed 24 August 2011.

${ }^{3}$ Kateb, Vahe G (2003), 'Australian press coverage of the Armenian genocide 1915-1923', MA thesis, University of Wollongong, 265-67, at http://ro.uow.edu.au/theses/215 accessed 24 August 2011. 
Australia's Gallipoli experience and the Armenian genocide, Robert Manne has poignantly observed that 'not one Australian historian has devoted more than a passing page or paragraph to the relationship, or even the mere coincidence, of the two events'. ${ }^{4}$ Consequently, the Armenian death toll has no role in Australia's collective memory of Gallipoli, only a memory and a noble story about that bloodied venue as the birthplace of a nation. This essay helps redress that omission by focusing on the role Australians played in what is certainly the nation's first major international humanitarian relief effort.

\section{The Armenian Genocide}

'The Armenian Question' emerged as an issue in international politics towards the end of the nineteenth century. The Ottoman Empire, which had ruled the largest portion of historic Armenia since the sixteenth century, had declined to the point where western diplomats came to call it 'the sick man of Europe'. The Armenians experienced increased political repression, religious persecution and heavy taxation. Following the Ottoman Empire defeat in the Russo-Turkish war of 1878, the European powers pressed the Ottomans to carry out reforms in the Armenian-inhabited regions of the Empire. $^{5}$ Abdul Hamid II, the sultan of the theocratic Ottoman Empire, was defiant. Between 1894 and 1896, a series of massacres were carried out against the Armenians, greatly shocking and alarming the western world. According to Dr Johannes Lepsius, a German missionary who witnessed and investigated the massacres, at least 100,000 Armenians were

4 Manne, Robert (2007), 'A Turkish Tale', The Monthly, February, 20.

${ }^{5}$ Walker, Christopher J (1990), Armenia: The survival of a nation, London, Routledge, 114. 
killed and another 500,000 made destitute. ${ }^{6}$ Winston Churchill and several American writers and journalists were openly using the word 'holocaust' to describe these events. ${ }^{7}$

In July 1908, a group of secularist revolutionaries known as the 'Young Turks' launched a coup and within days they removed the autocratic powers of Sultan Abdul Hamid, making him a constitutional monarch. In March 1909, the Sultan mounted a counter-coup. Initially successful, he was ultimately deposed by the Young Turks. During this turbulent period, another large-scale massacre of Armenians was launched in the Adana province of southern Turkey, one in which approximately 20,000 Armenians perished. ${ }^{8}$ After a series of military defeats and the loss of Ottoman territory in the Balkans to its former Christian subjects in 1912-1913, the Young Turks decided to follow a strategy of aggressive, narrowly ethnic Turkish political and linguistic nationalism. Fearing that the Armenian provinces would also be lost with the intervention of foreign powers, the Young Turks began to regard Armenians with increased suspicion. ${ }^{9}$

In October 1914, the Ottoman Empire-after much debate and dithering - entered World War I on the side of Germany. After a series of Ottoman military setbacks by the Russians, the Young Turks accused the Armenians of conspiring with the Russian forces to ensure an Ottoman defeat. The legend of 'Armenian treachery' gave the government the pretext to

${ }^{6}$ Lepsius, Johannes (1897), Armenia and Europe: An indictment, London, Hodder and Stoughton, 18.

7 Tatz, Colin (2003), With Intent to Destroy: Reflecting on genocide, London, Verso, 18, 186.

8 Akçam, Taner (2006), A Shameful Act, New York, Henry Holt and Co, 69 .

${ }_{9}$ Nezim, Seker (2007), 'Demographic Engineering in the Late Ottoman Empire and the Armenians', Middle Eastern Studies, vol 43, no 3, May, 462. 
sanction measures designed to remove all traces of the Armenian population from the Empire. Triggered by what many scholars argue was the impending landing by the Anglo-French forces on the Gallipoli peninsula, the Young Turk government arrested some 250 Armenian intellectuals in the capital, Constantinople (now Istanbul), on 24 April 1915.10 This marked the beginning of what Henry Morgenthau, the United States ambassador to the Ottoman Empire in 1915, described as a 'campaign of Race extermination'. ${ }^{11}$

Soon afterwards, the Minister of the Interior of the Ottoman Empire, Talaat Pasha, ordered the deportation of Armenians throughout Ottoman Turkey. Their properties were seized and the deportees given insufficient provisions to sustain life. Forced to march through hostile terrain, tens of thousands died from starvation and disease. There was no security and columns of people were set upon, robbed, raped, abducted or killed by paramilitaries, by Kurdish brigands, released prisoners and gendarmes under the control of party officials or local governors. The Armenians had, as Geoffrey Robertson QC observes, 'been deliberately ordered to suffer "conditions of life calculated to bring about their destruction in whole or in part"'.12 During the death marches, tens of thousands of Armenian women and children were abducted and were forcibly converted to Islam as a price for their lives. ${ }^{13}$

10 The Monthly, February 2007, 21.

11 Internal Affairs of Turkey 1910-1929, General Records of the Department of State, Document, no 867.4016/76, Cable Record Group 59, US National Archives, Washington DC.

12 Robertson, Geoffrey QC, Was There an Armenian Genocide?, London, Doughty Street Chambers, 2009, 5.

${ }^{13}$ Akçam, Taner, 183. 


\section{Anzac prisoners of war as witnesses}

Among the plethora of foreign eyewitnesses to the Genocide were the Anzac prisoners of war taken by the Turks. They include prisoners captured at Gallipoli, the Sinai, Mesopotamia and the submariners who penetrated the Dardanelles in 1915.14 Perhaps the most well-known Australian prisoner in Turkey was Captain (later Sir) Thomas White, a pilot for the Australian Flying Corps, and in later years a cabinet minister in the Menzies government. White was captured by the Ottoman army in November 1915 while on a mission to cut telegraph wires near Baghdad. He had his first encounter with the Armenian massacres when he reached a 'mainly Armenian town' called Tel Armen in northern Mesopotamia. He noticed that only a very few Armenian women and children had remained, 'the males being conspicuously absent'. After climbing a little rise, he found 'thirty-six newly-made graves which spoke eloquently of what had become of the Armenian men'. He noticed a little girl who had been watching him from a side street and looked pleadingly towards him. Powerless to help her, White was 'horrified at the Turk's handiwork, learning later that these massacres had been simultaneous and to order throughout the entire country' ${ }^{15}$

In addition to the demographic change brought about by the forced deportation of Armenians and other Ottoman Christians, the policy had served another useful purpose for the Ottomans. The homes, churches and monasteries the Armenians were forced to abandon became the prison camps

14 See Diamadis, Panayiotis (2007), 'Precious and Honoured Guests of the Ottoman Empire', Genocide Perspectives II, Blackheath, Brandl and Schlesinger.

15 White, Thomas W (1928), Guests of the Unspeakable: The odyssey of an Australian airman - being a record of captivity and escape in Turkey, London, John Hamilton Ltd, 122. 
where many Australian and other Allied prisoners were held captive. Lieutenant Leslie H Luscombe of the 14th Battalion AIF was taken prisoner at Gallipoli on Hill 971 in August 1915. While being transported to the centuries-old Sourp Asdvadzadzin (Holy Mother of God) Armenian monastery in Ankara, he witnessed 'a sad and depressing sight' at the station in Eskisehir, a railway junction town in western Turkey:

On the opposite side of the platform another train was standing. It was composed of a number of empty two-tier steel sheep trucks. On the platform a considerable number of Armenian women and children were huddled together. As our train pulled into the platform, Turkish soldiers armed with whips were driving the women and children into the sheep trucks. It was evidently intended to transport them to some distant concentration camp... All the Armenian men that could be rounded up were liquidated. ${ }^{16}$

Another prisoner was Able-Seaman John H Wheat, a crew member of the Australian submarine 'AE2', which was captured shortly after penetrating the Dardanelles in April 1915. He was taken to the Sourp Asdvadzadzin Armenian church at Afyon Karahissar, a town in western Turkey. Before the war, the Armenians comprised about one-third of the town's 30,000 inhabitants. Wheat observed that 'all the Armenians' had been 'driven from the town' before his arrival. Another prisoner interned at Afyon, George Handsley of the 2nd Australian Light Horse Unit, describes how the town 'had been the scene of a horrible massacre' before his arrival, adding that 'blood stains' were 'still there, and were quite plain on the wall of our quarantine prison room' ${ }^{17}$

${ }^{16}$ Luscombe, Leslie H (1970), The Story of Harold Earl: Australian, Brisbane, W R Smith \& Paterson, 52-53.

${ }^{17}$ Foster Joseph R, Two and a Half Years Prisoner of War in Turkey, 
John Halpin, of the 12th Light Horse Regiment, captured in the Sinai, described his 'new-found home' at Afyon:

We live in an atmosphere of desecration - the desecration of the House of Christ, and His martyred children of Armenia. This was their structure, is now their resting place. By day the blood-bespattered walls cry out to us, imagination magnifies the shrieks of massacre by night. Within the narrow churchyard, their bones lie underfoot. ${ }^{18}$

Curious to know what had happened to the Armenians, Halpin caught the attention of a Turkish officer named Abu Makarish, passing him a few para's for information. Makarish related to Halpin how he had 'killed Armenians' sweeping his hands 'across his throat from ear to ear, in a sequence of significance' about eight times. Makarish gestured again in 'a sequence of significance...Women...screaming, childish victims of his ravishments'. ${ }^{19}$

\section{The Armenian relief movement}

The relief movement to save Armenian survivors began in the United States in 1915. It was sparked by a telegram sent by the United States ambassador, Henry Morgenthau, to the Secretary of State in Washington on 6 September 1915. Morgenthau reported that the 'destruction of the Armenian race' was 'progressing rapidly' and he proposed the formation of a relief fund in the United States to 'provide means to save some of the Armenians' who had survived. ${ }^{20}$ In response to his appeal, an emergency meeting was held in

Series no A1336, Acc no A1336/1, at www.naa.gov.au accessed 10 September 2011.

18 Halpin, John (1934), Blood in the Mists, Sydney, Macquarie Head Press, 216

19 Ibid.

${ }^{20}$ Internal Affairs of Turkey 1910-1929, General Records of the Department of State, Document no 867.4016/117, Cable Record Group 59, US National Archives, Washington DC. 
New York on 16 September 1915 by a group of civic, business and religious leaders. They formed the American Committee for Armenian and Syrian Relief (ACASR), with headquarters in New York. Steps were taken immediately to organise volunteer committees in every state in the nation to maximise the Fund's outreach to the American people. The ACASR was eventually incorporated by an Act of Congress in August 1919 and renamed Near East Relief (NER). Within a decade, the organisation had successfully raised over $\$ 110$ million and rescued more than a million Armenians, Greeks and Assyrians from certain death. This figure included over 130,000 children who were housed, fed and educated in more than 200 orphanages. ${ }^{21}$ The American Red Cross was also involved in sending relief supplies to the Near East and by 1918 they had appropriated about \$US1.8 million for Armenian relief.

Britain soon followed America's lead and in October 1915 the Lord Mayor of London, Charles Johnson, inaugurated the Armenian Refugees (Lord Mayor's) Fund at Mansion House, London. In British cathedrals and churches it became the practice to designate a Sunday in February as 'Armenia Sunday', and to give the proceeds of the collections to Armenian relief. By the end of World War I, British charities had raised tens of thousands of pounds for the Armenian refugees. $^{22}$

\section{Australia's role in the relief effort}

The fate of the Armenians aroused the sympathy of many Australians. In December 1915, Miss M E Searle, honourable

${ }^{21}$ See Barton, James (1930), Story of Near East Relief: 1915-1930, New York, MacMillan \& Co.

22 Nassibian, Akaby (1985), Britain and the Armenian Question: 19151923, London, Croom Helm, 63. 
secretary of the newly-formed Armenian Relief Fund, made an appeal by letter to the editor of the Melbourne Argus. Searle stated that the Young Turks were bent on 'exterminating the Armenians' and had made 'appalling progress' towards this goal. She urged fellow Australians to follow the American lead and to 'spare something for these most pitiful of all'.$^{23}$

The Fund had emerged from a large wartime Australian culture of relief movements for various countries, such as the Belgian Relief Committee, Serbian Relief Committee and Polish Relief Committee. Searle's efforts helped raise a modest $£ 300$ until her work was taken over by the Friends of Armenia organisation in early 1917. The organisation was formed in Melbourne by three prominent citizens: Dr Alexander Leeper, Master of Trinity College in the University of Melbourne, William H Edgar MLC, and Pastor James E Thomas, President of the Council of Churches of Victoria. ${ }^{24}$ In February 1917, a public meeting was held in the Assembly Hall, Collins Street, Melbourne, by the Friends of Armenia committee, chaired by William H Edgar. The stated purpose of the meeting was to awaken 'fresh interest in the cause' of the Armenians. A motion was put forward by members of the committee calling for

the attention of the public to the urgent needs... of the remnant of Armenia. We are convinced that their claims for help are so strong that the whole civilised world should cooperate forthwith to save them. We trust that the government of Australia and the community at large will take up their cause, so that, where possible, protection and help may be given, and that liberal supplies of money may be received. ${ }^{25}$

${ }^{23}$ Babkenian, Vicken (2010), 'An SOS from Beyond Gallipoli: Victoria and the Armenian Relief Movement', Victorian Historical Journal, vol 81 , no $2,257$.

24 Ibid, 257.

25 Ibid, 258. 
In response to requests made by the Friends of Armenia committee, the Lord Mayor of Melbourne, Sir David V Hennessy, convened a meeting with the Council of Churches of Victoria in March 1917. He suggested that 'the various Churches should set apart a Sunday for special collections in aid of the suffering Armenians'. They agreed to designate 22 April 1917 as 'Armenia Sunday', a day for intercessions and collections for the starving Armenians. The Lord Mayor proclaimed:

I gladly accede to the request made to me by several prominent citizens of Melbourne, and by the Victorian Friends of Armenia Committee, to open a fund for the relief of the remnant of Armenia. Many of these poor people are dying through starvation in Mesopotamia and Arabian Deserts, whilst others who are returning to Armenia are in urgent need of help and the re-establishment of their desolated homes. ${ }^{26}$

This initiative by the Lord Mayor, supported by the Church leaders in Victoria, became the first major grassroots drive for destitute Armenians. The appeal was a great success; the Melbourne Age reported that over $£ 2,000$ had been collected. A ladies subcommittee was formed and some bales of goods were made up for transport to Armenia at the earliest opportunity. Unfortunately, the lack of shipping facilities prevented their dispatch. ${ }^{27}$

The Commonwealth Button Fund ( $\mathrm{CBF}$ ), an organising body which co-ordinated and sponsored the fundraising activities of other funds, produced a badge to help with the Armenian relief campaign in November 1917.28 It featured a

26 'Appeal for Distressed Armenia', Argus, Melbourne, 21 April 1917, 16.

27 ‘Help for Armenia - Over $£ 3000$ raised', Age, 5 December 1917, 9.

28 Print for Badge: Servia Syria Armenia, National Archives of 
coloured illustration of a Middle Eastern scene, with date palms, a white town with minarets and three Arabs on camel against yellow sand and a blue sky. The words 'Servia Syria Armenia' were printed in red across the sand. During the war these badges were sold in trams, buses, at railways stations and rallies to raise money for the stated cause.

Before long, the movement for Armenian relief spread across to other Australian states. In December 1918, the Lord Mayor of Sydney, James J Smith, along with many prominent businessmen and clergy, adopted a resolution put forward by Sir Thomas Anderson calling for a 'fund to be established in NSW...to save a Christian people, who are now living in abject poverty, from extinction' ${ }^{29}$

In a pioneering move to increase collections, the New York based ACASR commissioned a veteran Hollywood film producer, William N Selig, in early 1919 to produce a film based on the story of Aurora Mardiganian, an Armenian girl who had survived the genocide. The Armenian relief committees in Australia received a copy of the six-reel film and eagerly used it as an effective fundraising tool. On 28 February 1920, the Union Theatres Ltd under the auspices of the Sydney and Melbourne Armenian relief committees, presented a premiere at the Princess Theatre in Spring Street, Melbourne. ${ }^{30}$

While only one reel of the film has survived, a book entitled The of Souls: The Story of Aurora Mardiganian first published in 1918, provides the screenplay. It opens in an Anatolian village on Easter Morning 1915, where the large

Australia, Series no A1861, Acc no 3905, at www.naa.gov.au accessed 8 August 2011.

${ }^{29}$ Babkenian, Vicken (2008), 'Edith May Glanville: Champion of the Armenian Relief Fund', Journal of the Ashfield and District Historical Society, 8.

30 'Aid for Armenia', Herald, 28 February 1920, 6. 
Mardiganian family is preparing for the forced deportation. On the road, Aurora is continuously molested and she finally apostatises in order to save her mother, but to no avail. At a certain point during the exodus, 16 girls in the caravan are 'crucified' on crude crosses - the most sensational scene in the film. Aurora is finally rescued and taken to Russia, where she embarks on a Norwegian ship for the United States. ${ }^{31}$ It was the first movie ever made explicitly for the work of advocacy for humanitarian relief. It was described by the Melbourne Herald as the 'most powerful human drama of all time' ${ }^{32}$

\section{The internationalisation of the Armenian Relief movement}

In May 1922, the Reverend Dr Lincoln L Wirt, an American Congregational minister and the International Commissioner of the NER, visited Australia to organise and expand Australia's relief potential. He had spent much time in the Near East and had been directly involved in the relief work. Prior to his arriving, Wirt had helped establish committees in Hawaii, Japan, China, and the Philippines. ${ }^{33}$ The stated aim of his mission was to 'forge a chain of mercy' from one end of the world to the other.

Wirt travelled to the major capital cities in Australia where public meetings were organised. He spoke of the dire needs of

${ }^{31}$ Gates, H L (1919), The Auction of Souls: The story of Aurora Mardiganian, the Christian girl who survived the Great Massacre, London, Odhams Press.

32 Babkenian, Vicken (2010), 'An SOS from Beyond Gallipoli', 'An SOS from Beyond Gallipoli: Victoria and the Armenian Relief Movement', Victorian Historical Journal, vol 81, no 2, 261.

33 Babkenian, Vicken (2010), 'Cuba, China, Korea, Hawaii and the Armenian Genocide', Armenian Weekly, 10 November, available at http://www.armenianweekly.com/2010/11/10/cuba-china-koreahawaii-and-the-armenian-genocide/ 
the Armenians and called on Australian government to provide a 'mercy ship' for goods donated by Australians to be sent directly to the areas of need. The heads of the major religious organisations, as well as prominent political and civic leaders, expressed their support. The Prime Minister of Australia, William 'Billy' Hughes, promised 'that free freight would be provided by the Commonwealth Steamers' ${ }^{34}$

As a result of appeals made in Melbourne, Sydney and Adelaide during Wirt's visit, shipments of relief supplieswhich included flour, tinned milk, clothing, leather and woollen material-were dispatched aboard the Commonwealth Government steamers, Hobson's Bay and Parratah. The supplies were escorted by Miss Hilda J King, the daughter of the Reverend Joseph King, formerly organising agent of the London Missionary Society in Australia. ${ }^{35}$

Before returning to the Near East, Wirt had succeeded in forming relief committees in every state in the Commonwealth. He expressed his delight at the result of his mission, which had far exceeded his greatest expectations: 'I have never seen anything like the generosity of the Australian people. I look upon it all as more beautiful than anything else in my life.'36 On 16 September 1922, shortly after Wirt's departure, news of the destruction of the port city of Smyrna at the hands of the Turkish nationalists reached Australia. ${ }^{37}$ Fire had been set to the Armenian quarter, spreading ferociously to the Greek and European quarters. Over 300,000 Armenians and Greeks fled to the quay for safety and were

34 'Starving Armenia - Public Appeal', Sydney Morning Herald, 9 August 1922, 12.

35 'Armenian Relief - flour from Victoria', Argus, 6 September 1922, 19.

36 'Armenian Relief - Victoria's first contribution', Argus, 5

September, 1922, 9.

37 'Smyrna Burning', Argus, 16 September 1922, 25. 
later removed to Greece as refugees. The Reverend Dobson, previously an Anzac chaplain at Gallipoli, witnessed the catastrophe and was involved in providing relief to the victims of the tragedy. He later wrote a detailed report on the event, poignantly titled 'The Smyrna Holocaust'. ${ }^{38}$

In November 1922, with the help of Wirt, the Australian committees established an orphanage in Antilyas, Beirut, named the 'Australasian Orphanage'. ${ }^{39}$ The orphanage initially housed some 1,700 Armenian children who had no responsible living relatives upon whom they had any moral or legal claim for support. The site was previously a paper mill and was well supplied with fresh water. It was partly surrounded by an orange grove on one side and the Mediterranean Sea on the other, which became a convenient bath house for the orphans. The motto of the orphanage was 'Hold Fast to Honour'. 40

\section{Letting the public know}

In their drive to educate the public, the Armenian Relief committees prepared a number of pamphlets containing vivid descriptions and photographs portraying the plight of the Armenians. One of them-titled 'An SOS from Beyond Gallipoli'-included an excerpt from an 'authenticated' telegram purportedly sent by Talaat Pasha to the provincial governors in 1915 stating: 'the government has decided to complete the extermination of all Armenians resident in Turkey, without regard to whether they are women, children or invalids' ${ }^{41}$

38 Dobson, The Reverend Charles (1923), The Smyrna Holocaust, London, The Anglo-Hellenic League.

39 'New orphanage at Beirut', New York Times, 16 November 1922, 3.

40 Babkenian, Vicken 'Edith May Glanville', 11.

41 ‘Relief of Distress: Armenia’, National Archives of Australia, Series 
The Australian daily newspapers provided invaluable assistance to the relief committees. From the early days in 1915, when Miss M E Searle made her first appeal until the early 1930s, the daily papers gave liberal space to news items on various phases of the relief work. The official organ newspapers and magazines of Australian religious and humanitarian organisations - such as the Red Cross Record and the Australian Christian World-gave prominent coverage to the Armenian relief appeal. The South Australian Armenian relief committee went as far as publishing a magazine titled the Armenian, with the intention of awakening the interest of the public towards the Armenian plight. ${ }^{42}$

In a bold attempt to grapple with the problem of supporting such a vast number of orphans, the South Australian committee announced in 1922 the formation of the Armenian Adoption Association, appealing for 2,000 members. Soon after, the Sydney committee developed its own way of helping the orphans with the 'Big Ten' movement. Members were requested to ask ten of their friends to subscribe 6 shillings per week for one year to be paid to the member as their 'Captain'. The money's collected were used to 'rescue, feed, clothe, and educate' a 'helpless' Armenian child for a year. ${ }^{43}$

Because of the strict censorship practiced by the Ottoman government during the war, visual publicity illustrating the Armenian plight was generally unavailable until after the war. Following the armistice, moving picture companies with the assistance of the NER, produced a number of

no A457, Acc no A457/1, at www.naa.gov.au accessed 24 August 2011.

42 Babkenian, Vicken (2009), 'A Humanitarian Journey: The Reverend James Edwin Cresswell and the Armenian Relief Fund', Journal of the Historical Society of South Australia, no 37, 68.

43 Australian Christian World, 30 March 1923, 16. 
documentaries for educational purposes. Many of these films made their way to Australia, such as 'Alice in Hungerland' and 'Jackie in the Near East'. The latter documentary was based on the work of Jackie Coogan, a famous child movie actor in America, who was involved in helping promote the cause of the destitute Armenian and Greek children in 1924. Arguably the first 'celebrity humanitarian', Coogan successfully helped gather a shipment of over one million dollars worth of supplies donated by the children of America. As the leader of the 'children's crusade', Coogan accompanied the shipment and was given a royal welcome by the orphans when he arrived at the orphanages in the Near East. ${ }^{44}$ Another documentary, entitled 'Uncle Australia Sees It Through', illustrating Australia's role in the relief effort, was also produced by the NER, and shown to gatherings across Australia. 45

\section{The Revered James Edwin Cresswell's tour of inspection}

In December 1922, at a conference held in Melbourne by the interstate representatives of the relief committees, it was decided to form a national executive committee. The Reverend James E Cresswell, a Congregational minister from Adelaide, was appointed unanimously as National Secretary of the Australasian Armenian Relief Fund. Cresswell was asked by the committee to make a tour of the Near East and report on the work being carried out. In January 1923, Cresswell embarked on his mission aboard the Hobson's Bay. He was accompanied by Melbourne nurse, Miss G Gordon,

\footnotetext{
44 Babkenian, Vicken (2011), 'Hollywood's First Celebrity Humanitarian That America Forgot', Armenian Weekly, 7 January, available at http://www.armenianweekly.com/2011/01/07/hollywoods-firstcelebrity-humanitarian-that-america-forgot/ ${ }^{45}$ Babkenian Vicken, 'Edith May Glanville', 11.
} 
who had volunteered to engage in relief work at the Australasian Orphanage. Part of their equipment was a large Australian flag to be used as a symbol of Australia's humanitarian presence overseas. ${ }^{46}$

Cresswell's first destination was Syria, the epicentre of the relief operations. After having disembarked at the port of Antioch, Cresswell and Miss Gordon travelled eastwards to Aleppo. It was here that they first encountered the situation of some 6,000 Armenian and Greek refugees who had recently fled persecution in Turkey. Cresswell found the refugees clad in mere rags gathered apparently from the 'rubbish heaps of years'. They had sought shelter in caves which had previously been used as slaughter houses. One of the caves was set apart as a field hospital treating patients suffering from pneumonia and tuberculosis. Another was used as a church. Cresswell recorded his observations:

The sights within these caves are beyond words. No words seem adequate to describe the misery that must be the portion of these poor people... Here were women pale and emaciated, children with swollen abdomens, the result of starvation. Again, one saw little babies pinched and pallid further on a little one just recently born, one tiny atom among thousands of the suffering children to be seen here. ${ }^{47}$

Travelling in a south-westerly direction on a bleak journey through arid and barren grasslands, the pair arrived at Antilyas in February 1923, warmly received at the Australasian Orphanage. They were greeted by the directors, $\mathrm{Mr}$ and Mrs John $\mathrm{H}$ Knudsen of New Zealand, whom Cresswell described 'as the most efficient heads of orphanages' he had met. ${ }^{48}$ Present also was Miss Hilda King

46 Babkenian, Vicken, 'A Humanitarian Journey', 69.

47 'The Armenian', Armenian Relief Fund Committee, Adelaide, May, 1923, State Library of South Australia, 4-5.

48 'Armenian Relief - work by Australian section', Argus, 7 August, 
who was conducting relief work amongst the orphans. Cresswell was presented with a beautiful embroidered tablecloth in appreciation on behalf of the orphanage teachers and workers. The desire was expressed that this should be used at the periodic gatherings in Australia of the national Armenian relief committee.

Cresswell toured the orphanage. He was impressed to find that in addition to receiving food and clothing, the boys had 14 different trades to choose from as a means towards their future self-support. ${ }^{49}$ The directors were assisted by about 40 teachers and vocational leaders, as well as the same number of women known as 'mothers' who attended to the food and clothing of the children. ${ }^{50} \mathrm{He}$ inspected the dormitories and noticed blankets which had recently arrived from Melbourne and remarked: 'It was delightful to turn over the corners of these blankets and find the name of a well-known Australian firm, and to know that in Australia we are ministering to such dire necessity as one sees here.' He continued to see a vast array of Australian brand products being consumed 'and heard of those who spoke with no little appreciation of South Australian honey'. He witnessed the orphans, some of them quite small boys, making boots out of leather from Sydney tanneries. Further on, he visited the bakery where Australian flour was being made into tiny loaves of bread which were an essential part of the orphans' diet. ${ }^{51}$

Cresswell departed Antilyas in March 1923 and continued his journey to refugee camps and orphanages in Palestine,

1923, 13.

49 'Feeding the Starving - Australians in Armenia', Argus, 21 April 1923, 6.

50 Argus, 7 August 1923, 13.

51 Argus, 7 August 1923, 13. 
Turkey, Southern Russia, Armenia and Greece before returning home from his tour aboard the Makura in August 1923.52

\section{The Armenian Relief Fund and Save the Children Fund}

In late 1919, Australian opera singer, feminist and peace activist, Cecilia A John, formed a branch of the Save the Children Fund, an organisation aimed at helping destitute children, in Melbourne, Victoria. A co-founder of the Women's Peace Army in 1915, John had previously worked with the International Red Cross in Geneva and the SCF in London. ${ }^{53}$

The refugee crisis in Greece reached its peak in 1923 when the total number of refugees from Turkey swelled to about 1.4 million, becoming the greatest single refugee movement in history to date. A relief worker observing the child refugees remarked: 'They have forgotten how to smile...Fear is the one emotion with which they are familiar. ${ }^{\prime 54}$ A large portion of the Armenian and Greek refugees had been settled in Salonika, the second largest city of Greece and capital of the northern prefecture of the same name. After protracted negotiations between Cecilia and the executive committee of the Armenian Relief Fund of Victoria, it was resolved to merge their appeals to one. The purpose was to render the greatest possible assistance to the humanitarian crisis engulfing the Near East. The co-operative association of the two funds was formally inaugurated at a meeting of elected representatives of both, held on 3 December 1923.55 The name of the new joint

52 Babkenian, 'A Humanitarian Journey', 72.

53 http://adbonline.anu.edu.au/biogs/A090484b.htm, accessed 28 April 2009.

${ }^{54}$ Freeman, Kathleen (1965), If Any Man Build: The history of the Save the Children Fund, London, Hodder and Stoughton, 32.

55 Annual Report: Victoria (1924), Save the Children Fund and Armenian Relief Fund, Save the Children Archives, Melbourne, 1925, 1. 
committee was the Save the Children Fund and Armenian Relief Fund (SCF \& ARF).

The Armenian Relief Fund of Victoria thereby terminated its connection with the NER administration, and automatically became associated with the activities of the Save the Children Fund International Union, and the Lord Mayor of London's Armenian Fund, which were intimately related by written agreement. The Chairman of this new joint committee was Meredith Atkinson, previously the director of tutorial classes at the University of Melbourne, and Dr Leeper the Vice-Chairman. The Armenian relief committee in Adelaide followed Melbourne's move and merged with the SCF. The Sydney and Perth committees on the other hand continued their association with the NER, and the headquarters of the Australasian Armenian Relief Fund moved to George Street, Sydney, in $1924 .{ }^{56}$

The SCF and ARF focused their attention on the humanitarian crisis engulfing Greece and Armenia sending large consignments of food and clothing to the refugee camps. The well known Melbourne firms, Swallow and Ariell, Myer Pty Ltd, Messrs C M Read \& Co, along with others generously assisted in the relief campaign. The Victorian and South Australian governments participated by allowing relief parcels donated to the SCF and ARF to be carried free of charge on their State railways. ${ }^{57}$

56 'Near and Far', Sydney Morning Herald, 11 September 1924, 5.

57 'Greek-Armenian Refugees', Argus, 22 March 1924, 37. 


\section{Australians in Greece}

Australians were also at the forefront in the relief work in Greece. Lieutenant George D Treloar, an Anzac veteran from Ballarat, Melbourne, was appointed as the League of Nations' representative at Salonika responsible for the settlement of refugees in eastern Macedonia and western Thrace in 1922. Within a year, he was handling more than 108,000 refugees. For his outstanding humanitarian work, Treloar was appointed to the Order of the Saviour (gold cross) by the Greek government, and a refugee village, Thrilorion, near Komotini, Greece, was named after him. ${ }^{58}$

Joice NanKivell was born in Ingham, Queensland in 1887 but had spent most of her childhood on a farm in Gippsland, Victoria. After the death of her brother during World War I, her father abandoned the farm and NanKivell went to Melbourne where she reviewed books for the Herald and worked as secretary to Professor Leeper at the University of Melbourne. In response to the Smyrna Catastrophe, Joice along with her Gallipoli veteran husband, Sydney Loch, volunteered to conduct relief work at a Quaker-run farm school near the teeming refugee camps of Salonika. They were joined by Caroline Ethel Cooper, daughter of the deputy Surveyor-General of South Australia, who had previously worked with the Lochs during the famine in Poland in 1921.

Caroline and the Lochs set about improving conditions for the refugee villagers, who found themselves without proper water supply or any form of medical assistance. To help the villagers become self-sufficient, Joice sourced wool and cotton, had a loom built, learned about natural dyes and formed a women's weaving co-operative called Pyrgos Rugs. She designed Byzantine style rugs, two of which are now on

$58 \mathrm{http}: / /$ adbonline.anu.edu.au/biogs/A120286b.htm accessed 3 May 2009. 
display: one in the Powerhouse Museum in Sydney and the other in the 12th century tower that is now the Loch 'Australian' Museum in Ouranoupolis, Greece. In addition to teaching the women and children literacy and economic skills, Loch acted as an assistant medical officer. Throughout her life, Loch maintained a keen interest in humanitarian work. During World War II she helped save thousands of Polish and Jewish children from the Nazis by leading a daring escape known as 'Operation Pied Piper'. She has been awarded more medals than any other Australian woman for her heroism, her humanitarian work, and her innovative programs instituted in various refugee camps throughout Europe. ${ }^{59}$

Caroline remained at the Quaker Relief unit in Salonika until 1928. Before returning to Australia in 1930, she assisted the work of Miss Karen Jeppe, the commissioner for the protection of women and children in the Near East, based in Aleppo, Syria. Jeppe had been appointed by the League of Nations to reclaim the thousands of Armenian women and children who had been abducted during the Armenian Genocide and forcibly converted to Islam. While visiting the headquarters of the Armenian Relief Fund of NSW in Sydney, Caroline thanked the New South Wales committee for the generous contribution towards Karen Jeppe's work. Caroline stated that 'Miss Jeppe much appreciated the help of Australia', and that the money sent had been 'used for a soup kitchen and a clinic for the orphan children'. ${ }^{60}$

\section{Australian women advocate the Armenian cause}

Australian women played a prominent role in the cause of

59 See de Vries, Susanna (2006), Blue Ribbons, Bitter Bread: The life of Joice NanKivell Loch, Australia's most heroic woman, Sydney, Pirgos Press-Tower Books.

60 `Near and Far', Sydney Morning Herald, 29 January 1930, 10. 
Armenian relief both on the field and at home. Three prominent feminists of Sydney, Lady Caroline Edgeworth David, Edith May Glanville and Eleanor Mackinnon (OBE), were the driving force behind the success of the Fund in NSW. Lady David, the wife of Sir Tannatt William Edgeworth David, a renowned geologist, became the president of the New South Wales branch of the fund in 1922. Lady David along with Edith Glanville, a well known social worker and honorary secretary of the fund, spoke at public gatherings in which branches of the fund were formed in towns across New South Wales. ${ }^{61}$ They also helped organise many fundraising events such as bazaars and fetes where needlework made by the orphans in the Near East were sold. During one of these events, Mrs Preston Stanley MLA, the first female member of the NSW Legislative Assembly, made this moving appeal on behalf of the Armenians:

When one reflects upon the moving history of that all too tragic nation...one is deeply concerned. Armenia is an honourable nation with one of the saddest histories...surely we will not be deaf to the cry of 120,000 orphans. ${ }^{62}$

Eleanor Mackinnon, the founder of the Junior Red Cross in 1914, was also a prominent member of the Armenian Relief Fund of New South Wales. In 1925, Eleanor was selected to represent Australia at the Sixth General Assembly of the League of Nations held at Geneva. She was invited to speak on the platform on the situation of the Armenian refugees by Fridjof Nansen, the President of the League of Nations. During her speech, Eleanor reminded the delegates that

the Armenians have lived in such a state of misery, persecution and suffering and have been subjugated to such atrocities as might well freeze our blood even to hear of them.

61 'Near and Far', Sydney Morning Herald, 8 May 1923, 8.

62 'Starving and Persecuted Armenians', Australian Christian World, 17 July 1925, 11. 
I do not wish to harrow your feelings, but I would ask you whether we are not indebted to this people. ${ }^{63}$

In Victoria, prominent feminist and academic, Jessie Webb, was also an outspoken advocate on behalf of the Armenians. Jessie was chosen as Australia's alternate delegate to the Fifth General Assembly to the League of Nations held in Geneva in 1924. On her return to Australia, Webb appealed to the women of Australia 'who live in such free and happy conditions' to show 'practical sympathy with Miss Jeppe's undertaking by raising the money necessary' for the rescue of Armenian women. ${ }^{64}$

In addition to Hilda King, Miss G Gordon, Joice Loch and Caroline Holmes, three other Australian women are known to have conducted relief work among the Armenian refugees. Leila Priest, a nurse from Tasmania, had joined the NER after having served in the US army during the war. She was sent to Alexandropol, Armenia, in 1919 where she provided relief to over 20,000 orphans who were being cared for by the NER. ${ }^{65}$ Another nurse, Isobel Hutton RRC, who had previously been with the AIF in Palestine, also joined the NER following the War. She was sent to Aleppo where she conducted relief work among the approximately 70,000 'wearied and frightened' Armenian refugees. ${ }^{66}$

In 1926, Edith Glanville was appointed as liaison officer between the League of Nations (the predecessor to the United

63 'Minutes of the League of Nations', 25 September 1925, National Library of Australia.

64 'Women in Harems', Argus, 12 March 1924, 7.

65 'The Armenian Atrocities - A Tasmanian Nurse's Experience', Mercury, 8 September 1925, 3.

66 Teal, Helen (1921), 'Public Health Nursing in the Near East', American Journal of Nursing, vol 21, no 11, 1 August, 791. 
Nations) and the NER organisation. ${ }^{67}$ In the same year, Glanville embarked on a journey to the Near East in order to investigate the condition of the Armenian refugees and orphans. She reported her findings at the NER conference which met prior to the annual League of Nations Assembly meeting at Geneva. ${ }^{68}$

\section{The Relief Fund wraps up}

By 1928, only a core group of 500 orphans had remained at the Australasian Orphanage, and by the following summer, it was closed. The orphanage program not only provided the orphans with a home but gave them the means for self support. The Armenian relief movement continued to exist in Australia until the early 1930s, during which time a vast number of Armenians and other Ottoman Christians had been saved from starvation and disease. Thousands of Armenian women and children had also been reclaimed through the work of Karen Jeppe which was generously supported by Australians. Cresswell eloquently expressed the significance this event had for his own beloved nation:

The generosity of the people of Australia had made the name of the Commonwealth known to almost every person in and around Athens. From Jerusalem in the south, up through Syria, Greece, Turkey, and even southern Russia, there sprang up the lips...words of thankfulness for the kindness of Australia. 69

\section{Conclusion}

Despite a strong connection between Australia's Gallipoli experience and the Armenian genocide, the latter does not form part of Australia's collective memory of Gallipoli today.

67 'The Near East: War Conditions in Syria', Sydney Morning Herald, 2 April 1927, 10.

68 Ibid.

69 'Grateful to Australia', Sydney Morning Herald, 31 October 1923, 5. 
Australia's response to the Armenian genocide provides an early instance of international humanitarian activism that served as a precursor to many further instances of Australian engagement in relief operations through the League of Nations and the United Nations.

The Armenian relief movement mobilised a broad spectrum of Australia's political, civic and religious leaders, with Australian women playing a prominent role. The relief campaign produced a generous response, culminating in the establishment of an Australian-run orphanage in the Near East. As a result of the global reaction to the Armenian genocide, a significant number of Armenians and other Ottoman Christians were saved from death and destitution. Through the Armenian Relief Fund, Australia became one of the leading countries in the world to help rescue the Armenians from oblivion. It was a landmark event which would see Australia enter the world stage as an international humanitarian force.

The conundrum lies in the dissonance between these two mindsets and behaviours: on the one hand, an outstanding set of achievements in humanitarian intervention for a victim community; on the other, an expungement of Armenian history at the hands of Turkey, a former enemy now embraced, almost 'loved', by modern Australia for helping the country 'find itself' as a nation, as a separate national identity rather than a sibling daughter of Mother Britain. Recent federal governments have sought to minimise criticism of these 'partners in war', to evade discussion of any of the genocidal issues involved. Given the extent to which state and federal governments supplied transport and waived charges to assist Armenian refugees, there was clearly governmental complicity in relief action. How, then, is it possible for recent governments to disassociate themselves from the events of 1915 to 1923 , and beyond? 